\title{
Metronomic cyclophosphamide attenuates mTOR-mediated expansion of regulatory $T$ cells, but does not impact clinical outcome in patients with metastatic renal cell cancer treated with everolimus
}

\author{
Inge M. Werter ${ }^{1}\left(\mathbb{D}\right.$. Charlotte M. Huijts ${ }^{1}$. Sinéad. M. Lougheed ${ }^{1}$. Paul Hamberg ${ }^{2} \cdot$ Marco B. Polee $^{3}$. \\ Metin Tascilar ${ }^{4} \cdot$ Maartje Los $^{5}$. John B. A. G. Haanen ${ }^{6} \cdot$ Helgi H. Helgason $^{7} \cdot$ Henk M. Verheul ${ }^{1} \cdot$ Tanja D. de Gruijl $^{1}$. \\ Hans J. van der Vliet ${ }^{1}$. for the Dutch WIN-O Consortium
}

Received: 22 September 2018 / Accepted: 2 February 2019 / Published online: 11 February 2019

(c) The Author(s) 2019

\begin{abstract}
Introduction Metastatic renal cell cancer (mRCC) patients have a median overall survival (mOS) of approximately 28 months. Until recently, mammalian target of rapamycin (mTOR) inhibition with everolimus was the standard second-line treatment regimen for mRCC patients, improving median progression-free survival (mPFS). Treatment with everolimus supports the expansion of immunosuppressive regulatory $\mathrm{T}$ cells (Tregs), which exert a negative effect on antitumor immune responses. In a phase 1 dose-escalation study, we have recently demonstrated that a low dose of $50 \mathrm{mg}$ oral cyclophosphamide once daily can be safely combined with everolimus in $\mathrm{mRCC}$ patients and prevents the everolimus-induced increase in Tregs. Materials and methods In a multicenter phase 2 study, performed in patients with mRCC not amenable to or progressive on a vascular endothelial growth factor (VEGF)-receptor tyrosine kinase inhibitor (TKI) containing treatment regimen, we assessed whether the addition of this metronomic dosing schedule of cyclophosphamide to therapy with everolimus could result in an improvement of progression-free survival (PFS) after 4 months of treatment.

Results Though results from this study confirmed that combination treatment effectively lowered circulating levels of Tregs, addition of cyclophosphamide did not improve the PFS rate at 4 months. For this reason, the study was abrogated at the predefined interim analysis.

Conclusion Although the comprehensive immunomonitoring analysis performed in this study provides relevant information for the design of future immunotherapeutic approaches, the addition of metronomic cyclophosphamide to mRCC patients receiving everolimus cannot be recommended.
\end{abstract}

Keywords Everolimus $\cdot$ Cyclophosphamide $\cdot \mathrm{mRCC} \cdot$ Tregs $\cdot$ mTOR

\begin{tabular}{|c|c|c|c|c|}
\hline \multicolumn{3}{|c|}{ Abbreviations } & APC & Allophycocyanin \\
\hline \multicolumn{2}{|c|}{ ABCB 1} & $\begin{array}{l}\text { ATP-binding cassette }(\mathrm{ABC}) \text { transporters } \\
\mathrm{B} 1\end{array}$ & CCMO & $\begin{array}{l}\text { Central Committee on Research Involvi } \\
\text { Human Subjects }\end{array}$ \\
\hline \multirow{2}{*}{\multicolumn{2}{|c|}{$\begin{array}{l}\text { ALDH1 } \\
\text { AN }\end{array}$}} & Aldehyde dehydrogenase 1 & CCR & $\mathrm{C}-\mathrm{C}$ chemokine receptor \\
\hline & & Absolute numbers & \multicolumn{2}{|l|}{ CT scan } \\
\hline \multicolumn{3}{|c|}{$\begin{array}{l}\text { Inge M. Werter } \\
\text { i.werter@vumc.nl }\end{array}$} & \multicolumn{2}{|c|}{$\begin{array}{l}\text { Department of Medical Oncology, Medical Center } \\
\text { Leeuwarden, Leeuwarden, The Netherlands }\end{array}$} \\
\hline$\triangle$ & $\begin{array}{l}\text { Hans } \\
\text { jj.vanc }\end{array}$ & $\begin{array}{l}\text { er Vliet } \\
\text { @ vumc.nl }\end{array}$ & \multicolumn{2}{|c|}{$\begin{array}{l}\text { Department of Medical Oncology, Isala Clinics, Zwolle, } \\
\text { The Netherlands }\end{array}$} \\
\hline & $\begin{array}{l}\text { Depar } \\
\text { Amste }\end{array}$ & $\begin{array}{l}\text { f Medical Oncology, Cancer Center } \\
\text { Amsterdam University Medical Centre, VU }\end{array}$ & \multicolumn{2}{|c|}{$\begin{array}{l}\text { Department of Medical Oncology, Saint Antonius Hospital, } \\
\text { Nieuwegein, The Netherlands }\end{array}$} \\
\hline & $\begin{array}{l}\text { Unive } \\
1117,\end{array}$ & $\begin{array}{l}\text { edical Centre, Vrije University, De Boelelaan } \\
\text { IV Amsterdam, The Netherlands }\end{array}$ & \multicolumn{2}{|c|}{$\begin{array}{l}\text { Department of Medical Oncology, Antoni van Leeuwenhoek } \\
\text { Hospital, Amsterdam, The Netherlands }\end{array}$} \\
\hline & $\begin{array}{l}\text { Depar } \\
\text { and V }\end{array}$ & $\begin{array}{l}\text { f Medical Oncology, Franciscus Gasthuis } \\
\text {, Rotterdam, The Netherlands }\end{array}$ & $\begin{array}{l}\text { Depar } \\
\text { Centr }\end{array}$ & $\begin{array}{l}\text { of Medical Oncology, Haaglanden Medical } \\
\text { Hague, The Netherlands }\end{array}$ \\
\hline
\end{tabular}




$\begin{array}{ll}\text { CTC } & \text { Common Toxicity Criteria } \\ \text { DLT } & \text { Dose-limiting toxicities } \\ \text { E:S ratio } & \text { Effector to suppressor ratio } \\ \text { FDA } & \text { Food and Drug Administration } \\ \text { ICH } & \text { International Conference on } \\ & \text { Harmonization } \\ \text { IMDC } & \text { International Metastatic RCC Database } \\ & \text { Consortium } \\ \text { METC } & \text { Medical Ethical Committee } \\ \text { mOS } & \text { Median overall survival } \\ \text { mPFS } & \text { Median progression-free survival } \\ \text { mRCC } & \text { Metastatic renal cell cancer } \\ \text { mTOR } & \text { Mammalian target of rapamycin } \\ \text { NCI-CTCAE } & \text { National Cancer Institute Common Toxic- } \\ & \text { ity Criteria grading system } \\ \text { ORR } & \text { Objective response rate } \\ \text { PD } & \text { Progressive disease } \\ \text { RCC } & \text { Renal cell carcinoma } \\ \text { SD } & \text { Stable disease } \\ \text { Tconv } & \text { Conventional T-helper cells } \\ \text { TKI } & \text { Tyrosine kinase inhibitor } \\ \text { WIN-O } & \text { Dutch Working Group on Immunotherapy } \\ & \text { of Oncology }\end{array}$

\section{Introduction}

Renal cell cancer (RCC) has been diagnosed in more than 84.000 new patients in the European Union each year and has resulted in almost 34.000 cancer deaths in 2012 [1]. Death due to RCC is mostly a consequence of metastatic disease, which occurs in $30 \%$ of patients at presentation and in an additional $30 \%$ of patients after initial nephrectomy [2]. Metastatic RCC (mRCC) is known to be resistant to chemotherapy. However, the prognosis of $\mathrm{mRCC}$ has greatly improved in the last decade with the registration of various novel therapeutics, resulting in a current median overall survival (mOS) of 28-29 months [3-6]. New drugs have been mostly tested in patients with clear cell mRCC, while papillary, chromophobic and oncocytic RCC and RCC of the collecting duct have been studied less due to their lower prevalence [7]. Until recently, first-line treatment of clear cell mRCC patients predominantly consisted of drugs that block the intracellular domain of the vascular endothelial growth factor (VEGF) receptor, such as sunitinib or pazopanib, resulting in a median progression-free survival (mPFS) of 11 months [8-10], or the combination of interferon-alfa (IFN- $\alpha$ ) and bevacizumab, the latter binding circulating VEGF, which resulted in an mPFS of 8.5-10 months [11-14]. Since 2007, drugs targeting the mammalian target of rapamycin (mTOR) pathway have been registered for the treatment of mRCC. Temsirolimus represents a firstline treatment option in poor-risk mRCC patients, while everolimus became a standard Food and Drug Administration (FDA)-approved second-line treatment in 2009 [10, 15-18]. The mTOR pathway influences cell growth, proliferation and angiogenesis, and mTOR inhibitor everolimus leads to an mPFS of approximately 4 months when used as second-line treatment $[16,19]$. Recently, the programmed cell death protein-1 (PD-1) checkpoint-inhibitor nivolumab, the c-Met and VEGF tyrosine kinase inhibitor (TKI) cabozantinib and the combination of lenvatinib (a multi kinase inhibitor) and everolimus were shown to be more effective compared to everolimus monotherapy and have thereby replaced everolimus as the standard second-line therapeutic approach in mRCC patients [3, 4, 20, 21]. In addition, combination therapy with PD-1 and cytotoxic T-lymphocyteassociated protein 4 (CTLA-4) immune checkpoint inhibitors nivolumab and ipilimumab was approved as a first-line treatment option for intermediate- and poor-risk patients [22].

One aspect potentially limiting the antitumor effect of mTOR inhibition by everolimus is their known stimulatory effect on regulatory $\mathrm{T}$ cells (Tregs) [23, 24]. Tregs are characterized by the expression of CD4, CD25 and the transcription factor forkhead box P3 (Foxp3), and are known to exert immunosuppressive effects, which can be beneficial in preventing overt autoimmunity, but can hamper the development of antitumor immune responses. Tumor cells or tumorassociated macrophages can produce ligands that selectively attract Tregs through $\mathrm{C}-\mathrm{C}$ chemokine receptor (CCR) type 4 , facilitating tumor cells to escape antitumor immunity [25, 26]. Studies have shown that the frequency of circulating as well as (peri)tumoral Tregs is negatively associated with survival in cancer patients, including mRCC patients [27-29].

We and others have shown that treatment with everolimus resulted in an expansion of peripheral blood Tregs [30,31]. As we hypothesized that the undesirable everolimus-induced expansion of Tregs in mRCC patients could be counteracted, we co-administered cyclophosphamide, which is an alkylating agent of the nitrogen mustard type that is known to selectively deplete Tregs (and not helper or cytotoxic $\mathrm{T}$ cells) [32-34]. The effect of cyclophosphamide on Tregs is not completely understood; however, several mechanisms have been proposed, including (a) induction of a DNA repair defect, (b) reduction of the ATP and glutathion content of Tregs and (c) causing a lack in the expression of the ATPbinding cassette (ABC) transporters B1 (ABCB1) [33-36].

We first performed a phase 1 dose-escalation trial, in which we established the optimal dose of metronomic cyclophosphamide that, when combined with the standard once daily oral dose of $10 \mathrm{mg}$ of everolimus, was safe, well tolerated and effectively reduced circulating levels of Tregs [37, 38]. In the present phase 2 study, we investigated whether the addition of the selected dose of metronomic cyclophosphamide would result in an improvement in mPFS as compared 
to everolimus monotherapy. In addition, immunomonitoring was performed to evaluate whether immune effects could be related to clinical outcome. The immunomonitoring performed in this study gives insight into the effects of mTOR inhibition and low-dose oral cyclophosphamide in cancer patients and thereby provides relevant information for the design of future treatments that incorporate or are based on mTOR inhibitors.

\section{Materials and methods}

\section{Patients and treatment}

The multicenter study was performed in medical centers that were part of the WIN-O (The Working group Immunotherapy of the Netherlands for Oncology) and included 29 patients of 18 years or older with clear cell mRCC who were not amenable to, or had progressed on, a VEGF receptor TKI regimen. As originally planned in the design of the study, 10 of the 25 patients had participated in the phase 1 part of this study, where they had been treated with the same treatment regimen as in the here reported phase 2 study. For a more extensive description of the inclusion and exclusion criteria of the study, we refer to the published study protocol [39]. Follow-up was until death or until the time of analysis (9 months after inclusion of the last patient). A pre-planned interim analysis was performed after 24 patients were treated for at least 4 months, to assess whether the primary objective, an increase of progression-free survival (PFS) at 4 months from 50 to $70 \%$ could be achieved. Since 12 out of 24 patients had progressed within the first 4 months of treatment, the study was terminated prematurely due to lack of efficacy. Secondary objectives that were studied included response rate, time to progression, overall survival and an assessment of the immunological effects of combination treatment.

Patients were treated with $10 \mathrm{mg}$ everolimus and $50 \mathrm{mg}$ cyclophosphamide orally, both once daily continuously. In case of severe toxicity, dose reductions were allowed according to protocol. Adverse events (AE) were defined in accordance with the International Conference on Harmonisation (ICH) Guideline for Good Clinical Practice (ICH E6:1.2). Severity of clinical AE was graded according to the National Cancer Institute Common Toxicity Criteria (CTC) grading system version 3.0 (NCI-CTCAE). Dose-limiting toxicities (DLT) were toxicities attributable to combination therapy within the first 28 days of therapy and defined as febrile neutropenia, neutropenic infection, other grade $\geq 3$ hematological toxicity, pneumonitis, nausea, vomiting, diarrhea, fatigue or any other grade $\geq 3 \mathrm{AE}$ that, despite appropriate supportive care, failed to recover to grade $\leq 1$ within 7 days [39]. Patients were evaluated at baseline and then every 4 weeks until the end of study treatment by means of history, physical examination and laboratory evaluation (hematology and chemistry). Moreover computed tomography scans (CT scan) of chest and abdomen were made at baseline and thereafter every 8 weeks. The objective response rate (ORR) was assessed clinically and radiologically, using Response Evaluation Criteria In Solid Tumors (RECIST, version 1.1).

\section{Immunomonitoring}

Immunomonitoring was performed at baseline and 4 weeks after the start of the study treatment period. Peripheral blood mononuclear cells (PBMC) were isolated by Lymphoprep (Axis-Shield, Oslo, Norway) density-gradient centrifugation, cryopreserved in liquid nitrogen, thawed and subsequently stained for $30 \mathrm{~min}$ at $4{ }^{\circ} \mathrm{C}$ with labeled antibodies in phosphate-buffered saline (PBS) supplemented with $0.1 \%$ bovine serum albumin (BSA) and $0.02 \%$ sodium azide. Based on the immunomonitoring results of the previously performed phase 1 study $[37,38]$, the following immune cell subsets were selected for monitoring in the present phase 2 study: regulatory $\mathrm{T}$ cells (Tregs, $\mathrm{CD} 4^{+} \mathrm{CD} 25^{\text {hi }} \mathrm{FoxP} 3^{\text {hi }}$ ), cytotoxic $\mathrm{T}$ cells $\left(\mathrm{CTL}, \mathrm{CD} 3^{+} \mathrm{CD} 8^{+}\right)$, B lymphocytes $\left(\mathrm{CD} 19^{+}\right)$, myeloid dendritic cells $\left(\mathrm{cDC} 1, \mathrm{BDCA}^{+} \mathrm{CD} 14^{-} \mathrm{CD} 11 \mathrm{c}^{+}\right.$ and $\left.\mathrm{cDC} 2, \mathrm{BDCA} 1^{+} \mathrm{CD} 19^{-} \mathrm{CD} 14^{-} \mathrm{CD} 11 \mathrm{c}^{+}\right)$and plasmacytoid dendritic cells (pDC, BDCA2 ${ }^{+} \mathrm{CD} 11 \mathrm{c}^{-} \mathrm{CD} 123^{+}$), immunoregulatory $\left(\mathrm{CD} 56^{\text {bright }} \mathrm{CD} 16^{\mathrm{dim}}\right)$ and cytotoxic $\left(\mathrm{CD} 56^{\mathrm{dim}} \mathrm{CD} 16^{+}\right)$natural killer cells (NK), and granulocytic $\left(\mathrm{Lin}^{-} \mathrm{CD} 14^{-} \mathrm{CD} 33^{+} \mathrm{HLA}^{-} \mathrm{DR}^{-}\right)$and monocytic $\left(\mathrm{Lin}^{-} \mathrm{CD} 14^{+} \mathrm{HLA}^{-} \mathrm{DR}^{-}\right.$) myeloid derived suppressor cells (MDSC).

The following antibodies were used: FITC-labeled antibodies against IgG1, CD4, CD14, CD16, BDCA1, BDCA2 and BDCA3; PE-labeled antibodies against IgG1, CD8, CD19, CD40, CD56, CD86 and CD123; PerCP-labeled antibodies against IgG1, CD3 and CD4; APC-labeled antibodies against IgG1, CD3, CD11c, CD25 and PD-1 (all these antibodies were obtained from BD Biosciences, New Jersey, USA). Intracellular stainings were performed after fixation and permeabilization using a fixation/permeabilization kit according to the manufacturer's protocol (eBioscience, Massachusetts, USA). The labeled antibodies used for intracellular stainings were PE-labeled IgG1, IgG2a, CTLA-4 and Ki-67 (all BD Biosciences, New Jersey, USA). FoxP3 was stained with anti-FoxP3 mAbs, either PCH101 PE (eBioscience, Massachusetts, USA) or 259D Alexa Fluor 488 (Biolegend, San Diego, USA). All cells were analyzed on a BD FACS Calibur and analyzed using Kaluza Analysis Software (Beckman Coulter). 


\section{Statistical analysis}

Paired $t$ tests were used to determine the statistical significance of differences between time points or groups. PFS was defined as the time from baseline until progression or death. Overall survival (OS) was defined as the time from baseline until death. Both PFS and OS were analyzed using Kaplan-Meier curves. Correlations were measured using Pearson correlation coefficient. Findings were considered statistically significant when $p$ values were $\leq 0.05$, as indicated with asterisks $(* p \leq 0.05, * * p<0.01, * * * p<0.001)$. Statistical analyses were performed using GraphPad Prism 6.0 software.

\section{Results}

\section{Baseline patient characteristics}

The study included 29 patients with clear cell mRCC who were treated at 12 different centers in the Netherlands between November 2013 and October 2016. Of these 29 patients, 25 patients were followed according to protocol; 4 of 29 patients were excluded within the first 2 weeks of the start of treatment. Three of them withdrew consent and one patient had inadvertently taken an inappropriate dose of cyclophosphamide. Patient characteristics are shown in Table 1 . Of the 25 patients included for study analysis, $60 \%$ were male, the median age of the study group was 66 years and $80 \%$ could be categorized in the favorable or intermediate IMDC risk group (prognostic model according to the International Metastatic Renal Cell Carcinoma Database Consortium, IMDC). The mean amount of white blood cells (WBC) was $6.4 \times 10^{9} / \mathrm{L}( \pm 0.38 \mathrm{SEM})$ and mean amount of lymphocytes was $1.45 \times 10^{9} / \mathrm{L}( \pm 0.13 \mathrm{SEM})$.

\section{Treatment efficacy and safety}

The median time of treatment of patients was 4.2 months (range 0.5-11 months). Two patients (8\%) still received treatment at the time of study termination, and all other patients had discontinued study medication due to progression $(n=19,76 \%)$ or unacceptable toxicity $(n=4,16 \%)$. Median follow-up was 7.9 months (range 0.5-21 months), based on time until death $(n=13,52 \%)$ or until time of analysis $(n=12,48 \%)$.

At the predefined interim analysis, it became evident that the primary objective of the study, an increase of PFS at 4 months from 50 to $70 \%$, could not be reached. At 4 months, $48 \%(n=12)$ of 25 patients had progressive disease. mPFS and mOS were 4.5 months (range 0.5-21 months) and 16 months (range 0.5-20 months), respectively (Fig. 1a, b). Three patients did not show signs of progression at the time of analysis (range 10-21 months) and 11 patients were still alive at the end of the follow-up period (range 10-21 months). The best clinical outcome was stable disease (SD) in $72 \%(n=18)$ of the cases. Progressive disease (PD) was observed in $28 \%(n=7)$ of the patients. No partial or complete responses were observed.

Overall, combination treatment was reasonably well tolerated. A total of 168 different AEs was reported, an average of 6.7 per patient. No grade 4 or 5 toxicities were observed. The most common $(>30 \%)$ treatment-related toxicities were fatigue $(n=11 ; 44 \%)$, anemia $(n=10 ; 40 \%)$, pneumonitis $(n=10 ; 40 \%)$, anorexia $(n=8 ; 32 \%)$ and hypercholesterolemia $(n=8 ; 32 \%$ ) (Table 2$)$. A total of 18 treatment-related grade 3 AEs were reported in $13(52 \%)$ patients. Grade 3 toxicities included fatigue, anemia, pneumonitis and leukocytopenia. Three patients $(12 \%)$ endured a DLT related to study medication within 28 days after the start of treatment, i.e., hematuria grade 3 , nausea grade 3 and mucositis grade 3 . In the case of the patient with hematuria, this resolved upon discontinuation of cyclophosphamide and the patient continued with everolimus treatment until disease progression. For the patient with nausea, study medication was interrupted and, due to rapid disease progression, not reintroduced. In the patient with mucositis, this resolved after a 14 day interruption of study medication and did not recur upon reintroduction of study combination therapy.

\section{Immune monitoring}

Based on the immunomonitoring results of the previously performed phase 1 study, a selective panel of immune cell subsets and ratios between immune cell subsets were analyzed in this phase 2 study: total $\mathrm{CD}^{+} \mathrm{T}$ cells, $\mathrm{CD}^{+}{ }^{+} \mathrm{CD} 4^{+}$conventional $\mathrm{T}$-helper cells (Tconv), $\mathrm{CD}^{+}{ }^{+} \mathrm{CD} 8^{+} \mathrm{CTL}$, Tregs, effector-suppressor $\mathrm{T}$ cell ratio or CD8:Treg ratio, defined as the ratio between $\mathrm{CD}^{+}$effector $\mathrm{T}$ cells and suppressive Tregs), immunoregulatory and cytotoxic NK cells, cDC1, cDC2 and pDC [31, 37, 38]. In the present study, the total amount of PBMC was $2.01 \times 10^{9 /} / \mathrm{L} \pm 0.13($ mean \pm standard error of mean $(\mathrm{SEM})$ at baseline and $1.86 \times 10^{9 /} / \mathrm{L} \pm 0.14$ after 4 weeks of treatment (not significant, NS). The total lymphocyte count was $1.45 \times 10^{9 /} / \mathrm{L} \pm 0.13$ at baseline and $1.25 \times 10^{9 /} / \mathrm{L} \pm 0.11$ after 4 weeks of treatment (NS).

\section{T cell subsets}

Neither the frequency nor absolute numbers (AN) of $\mathrm{CD}^{+}$ $\mathrm{T}$ cells in the total lymphocyte population changed significantly during the first 4 weeks of treatment (Fig. 2a). Also, the frequency as well as the absolute numbers of circulating $\mathrm{CD}^{+} \mathrm{T}$ cells did not change significantly (Fig. 2b). Of 
Table 1 Baseline characteristics

\begin{tabular}{|c|c|}
\hline Characteristic & Study group $(N=25)$ \\
\hline \multicolumn{2}{|l|}{ Sex-no. $(\%)$} \\
\hline Male & $15(60)$ \\
\hline Female & $10(40)$ \\
\hline Median age-year (range) & $66(48-78)$ \\
\hline \multicolumn{2}{|l|}{ ECOG performance status-no. (\%) } \\
\hline 0 & $11(44)$ \\
\hline 1 & $11(44)$ \\
\hline 2 & $1(14)$ \\
\hline Unknown & $2(8)$ \\
\hline \multicolumn{2}{|l|}{ IMDC risk group-no. $(\%)$} \\
\hline Favorable & $5(20)$ \\
\hline Intermediate & $15(60)$ \\
\hline Poor & $4(16)$ \\
\hline Unknown & $1(4)$ \\
\hline Median time from initial diagnosis to metastastic disease-mo. (range) & $12.5(0-174.5)$ \\
\hline Median time from metastastic disease to start study treatment-mo. (range) & $20(1-54.5)$ \\
\hline \multicolumn{2}{|l|}{ Site of metastases-no. $(\%)$} \\
\hline Lung & $18(72)$ \\
\hline Lymph nodes & $19(76)$ \\
\hline Bone & $6(24)$ \\
\hline Kidney & $4(16)$ \\
\hline Other* & $8(32)$ \\
\hline \multicolumn{2}{|l|}{ Number of metastatic sites-no. $(\%)$} \\
\hline 1 & $5(20)$ \\
\hline 2 & $9(36)$ \\
\hline 3 & $5(20)$ \\
\hline$\geq 4$ & $5(20)$ \\
\hline Unknown & $1(4)$ \\
\hline \multicolumn{2}{|l|}{ Previous systemic cancer therapy-no. (\%) } \\
\hline Sunitinib & $13(52)$ \\
\hline Pazopanib & $8(32)$ \\
\hline Interferon + bevazucimab & $1(4)$ \\
\hline Sorafenib & $1(4)$ \\
\hline \multicolumn{2}{|l|}{ Previous antiangiogenic regimens-no. (\%) } \\
\hline 0 or unknown & $6(24)$ \\
\hline 1 & $15(60)$ \\
\hline$>1$ & $4(16)$ \\
\hline
\end{tabular}

*Adrenal, liver, soft tissue, subcutaneous, peritoneum, breast

interest, a small but statistically significant increase in $\mathrm{CD} 8^{+}$ CTL was observed in frequency, and a similar, but not significant, trend was seen in absolute numbers (Fig. 2c).

The frequency and absolute numbers of circulating regulatory $\mathrm{T}$ cells $\left(\mathrm{CD} 4{ }^{+} \mathrm{CD} 25^{\mathrm{hi}} \mathrm{FoxP} 3^{\mathrm{hi}}\right)$ was found to significantly decrease from baseline to week 4 (Fig. 2d), confirming our previous observations. Of note, although the frequency of circulating Tregs decreased during the first 4 weeks of treatment, expression of the proliferation marker Ki-67 and the inhibitory CTLA-4 receptor in Tregs significantly increased (Fig. 2e, f).

As the ratio between $\mathrm{CD} 8^{+}$effector $\mathrm{T}$ cells and suppressive Tregs (E:S ratio) can have a prognostic impact [40], changes in this ratio were also assessed. As illustrated in Fig. 2g, the E:S ratio significantly increased from baseline to week 4 , reflective of a change in the relative distribution between $\mathrm{T}$ cell subsets toward a more favorable balance when considering antitumor immune responses. 


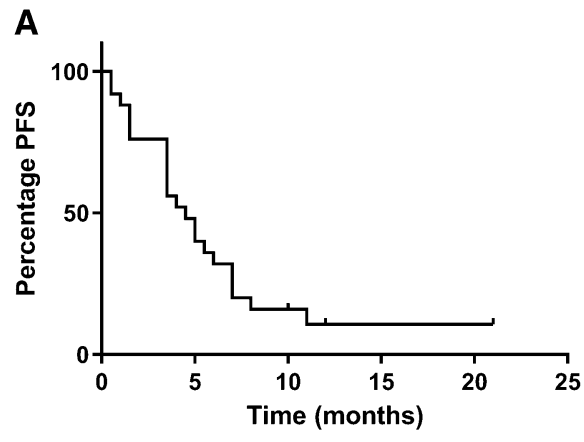

Fig. 1 Percentage Progression-free survival and overall survival on treatment. a Median PFS is 4.5 months (range $0.5-21$ months). At 4 months, $48 \%(n=12)$ of 25 patients had progressive disease. b Median OS is 16 months (range $0.5-20$ months). OS data are prelimi-

Table 2 Treatment-related toxicities, reported in $>10 \%$ of patients

\begin{tabular}{|c|c|c|c|c|}
\hline Event & Any grade $N(\%)$ & $\begin{array}{l}\text { Grade } 1 \\
N(\%)\end{array}$ & $\begin{array}{l}\text { Grade } 2 \\
N(\%)\end{array}$ & $\begin{array}{l}\text { Grade } 3 \\
N(\%)\end{array}$ \\
\hline \multicolumn{5}{|l|}{ Constitutional } \\
\hline Fatigue & $11(44)$ & $3(12)$ & $5(20)$ & $2(8)$ \\
\hline Anorexia & $8(32)$ & $2(8)$ & $6(24)$ & \\
\hline Malaise & $6(24)$ & $2(8)$ & $2(8)$ & $2(8)$ \\
\hline Pain & $4(16)$ & $2(8)$ & $2(8)$ & \\
\hline Fever/chills/flu & $3(12)$ & $3(12)$ & & \\
\hline Sweating/flushes & $3(12)$ & $3(12)$ & & \\
\hline \multicolumn{5}{|l|}{ Dermatology } \\
\hline Rash & $6(24)$ & $4(16)$ & $2(8)$ & \\
\hline Pruritus & $3(12)$ & $2(8)$ & $1(4)$ & \\
\hline \multicolumn{5}{|l|}{ Gastrointestinal } \\
\hline Nausea & $7(28)$ & $4(16)$ & $2(8)$ & $1(4)$ \\
\hline Mucositis & $7(28)$ & $4(16)$ & $2(8)$ & $1(4)$ \\
\hline Stomatitis & $6(24)$ & $4(16)$ & $1(4)$ & $1(4)$ \\
\hline Diarrhea & $5(20)$ & $5(20)$ & & \\
\hline Constipation & $3(12)$ & $1(4)$ & $2(8)$ & \\
\hline Dysgeusia & $3(12)$ & $2(8)$ & $1(4)$ & \\
\hline \multicolumn{5}{|l|}{ Laboratory } \\
\hline Anemia & $10(40)$ & $1(4)$ & $7(28)$ & $2(8)$ \\
\hline $\begin{array}{l}\text { Hypercholester- } \\
\text { emia }\end{array}$ & $8(32)$ & $2(8)$ & $6(24)$ & \\
\hline Hyperglycaemia & $6(24)$ & $1(4)$ & $4(16)$ & $1(4)$ \\
\hline Leukocytopenia & $6(24)$ & $1(4)$ & $3(12)$ & $2(8)$ \\
\hline $\begin{array}{l}\text { Hypertriglyceri- } \\
\text { demia }\end{array}$ & $5(20)$ & $2(8)$ & $2(8)$ & $1(4)$ \\
\hline Thrombocytopenia & $5(20)$ & $4(16)$ & & $1(4)$ \\
\hline $\begin{array}{l}\text { Electrolyte distur- } \\
\text { bance* }\end{array}$ & $4(16)$ & $4(16)$ & & \\
\hline \multicolumn{5}{|l|}{ Respiratory } \\
\hline Pneumonitis & $10(40)$ & $3(12)$ & $5(20)$ & $2(8)$ \\
\hline Dyspnea & $7(28)$ & $5(20)$ & $2(8)$ & \\
\hline Cough & $6(24)$ & $5(20)$ & $1(4)$ & \\
\hline
\end{tabular}

*Hyponatremia, hypokalemia, hypercalcemia

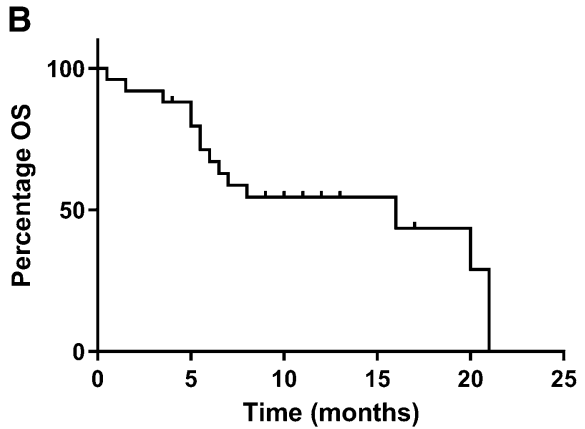

nary, as 11 patients (44\%) were still alive at the end of the follow-up period (range 4-20 months). Data were analyzed using a KaplanMeier curve

\section{Changes in natural killer (NK) cell populations}

After 4 weeks of treatment, a shift within the NK cell population occurred. There was a significant decline in both the frequency and absolute number of cytotoxic $\left(\mathrm{CD} 56^{\mathrm{dim}} \mathrm{CD} 16^{+}\right)$NK cells (Fig. 3a). In contrast, the immunoregulatory $\left(\mathrm{CD} 56^{\text {bright }} \mathrm{CD} 16^{-}\right) \mathrm{NK}$ cell population significantly increased in frequency, though not in absolute numbers (Fig. 3b). Overall, the effect of combination treatment of cyclophosphamide and everolimus on the NK cell balance was opposite to the effect observed with T cells and resulted in a more immunoregulatory NK cell profile.

\section{Circulating dendritic cell subsets}

Several blood dendritic cell subsets were monitored, including myeloid dendritic cells ( $\mathrm{cDC} 1$ and $\mathrm{cDC} 2)$ and plasmacytoid dendritic cells (pDC). After 4 weeks of treatment, a small, but non-significant, decrease in $\mathrm{CDC} 1$ cells was observed both in frequency and in absolute numbers (Fig. 3c). A significant increase in the frequency, but not in absolute numbers of $\mathrm{cDC} 2$ was observed (Fig. 3d). For pDC an increase was demonstrated in frequency as well as in absolute numbers (Fig. 3e). In addition to the frequency of circulating DC subsets, their expression of DC activation markers was monitored (data not shown). The activation status of $\mathrm{cDC} 1, \mathrm{cDC} 2$ and $\mathrm{pDC}$ did not significantly change, as measured by the expression of CD40, CD86 and CD123 (the latter only for $\mathrm{pDC}$, data not shown).

\section{Immunomonitoring and correlation with clinical outcome}

Overall, combination therapy with low-dose oral cyclophosphamide and everolimus did not improve the clinical outcome of patients when compared to everolimus monotherapy. However, as the combination of cyclophosphamide and everolimus resulted in a significant decrease 
Fig. 2 Change in lymphocyte subsets between baseline and 4 weeks of treatment. a Percentage of $\mathrm{T}$ cells $\left(\mathrm{CD}^{+}\right)$in total lymphocytes. b Percentage of $\mathrm{T}$ helper cells $\left(\mathrm{CD} 4^{+}\right)$in total $\mathrm{CD}^{+}$cells. c Percentage of cytotoxic $\mathrm{T}$ cells $\left(\mathrm{CD}^{+}\right)$in total $\mathrm{CD}^{+}$cells. d Percentage of regulatory $\mathrm{T}$ cells $\left(\mathrm{CD} 4^{+} \mathrm{CD} 25^{\text {hi }} \mathrm{FoxP}^{\mathrm{hi}}\right)$ in total $\mathrm{CD} 4^{+}$cells. e Percentage of $\mathrm{Ki}-67^{+}(\mathrm{Ki}-$ $67^{+} \mathrm{CD} 4^{+} \mathrm{CD} 25^{\text {hi }}$ FoxP $^{\text {hi }}$ ) in regulatory $\mathrm{T}$ cells. $\mathbf{f}$ Percentage of CTLA4 $4^{+}$ $\left(\mathrm{CTLA} 4{ }^{+} \mathrm{CD} 4^{+} \mathrm{CD} 25^{\mathrm{hi}} \mathrm{FoxP} 3^{\text {hi }}\right.$ ) in regulatory $\mathrm{T}$ cells. g E:S ratio. Effector $\left(\mathrm{CD}^{+}\right)$:suppressor $\left(\mathrm{CD} 4^{+} \mathrm{CD} 25^{\text {hi }}\right.$ FoxP $\left.^{\text {hi }}\right)$ ratio. Data were analyzed using paired $t$ tests. ${ }^{*} p \leq 0.05, * * p<0.01$, $* * * p<0.001$
A

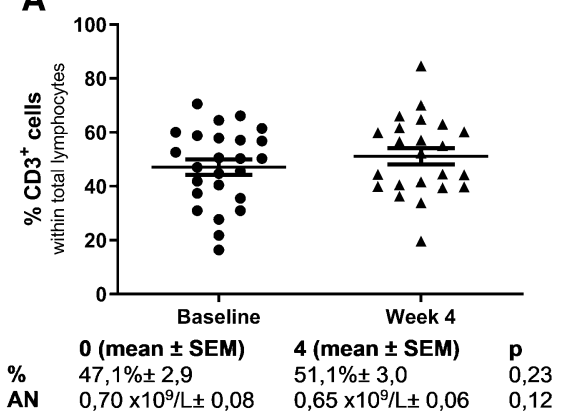

B

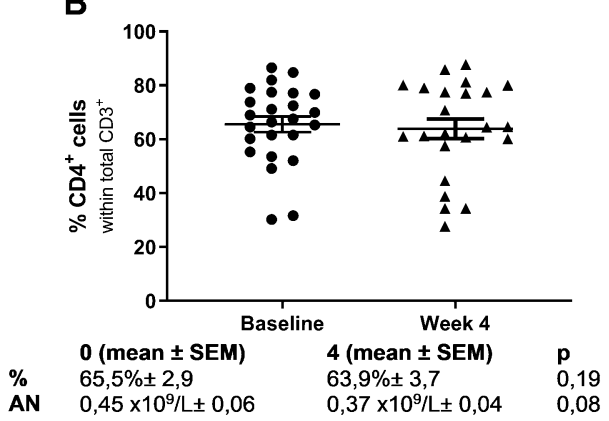

C

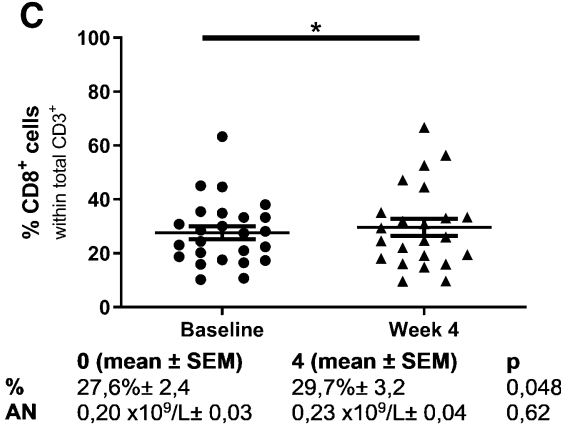

D

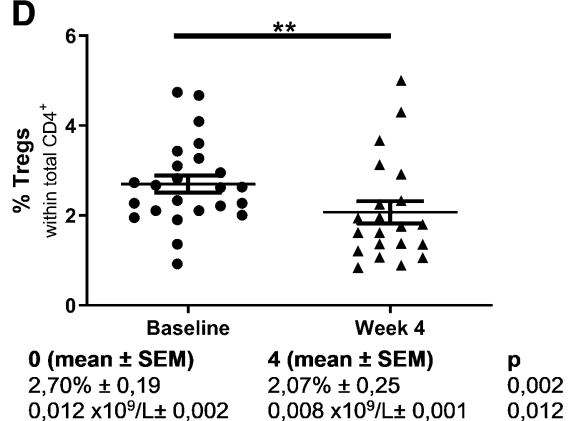

E

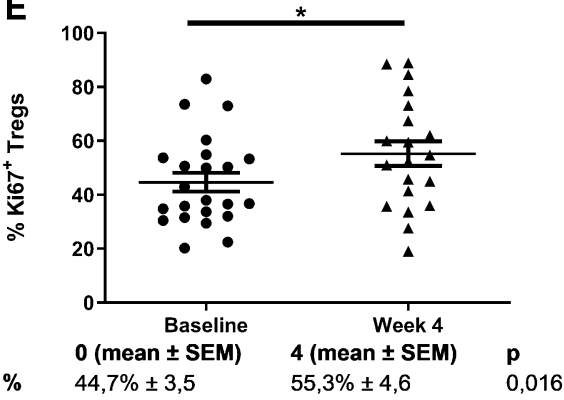

$\mathbf{F}$

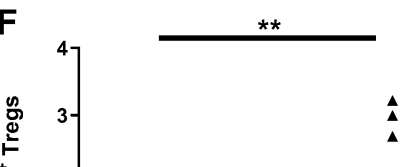

它

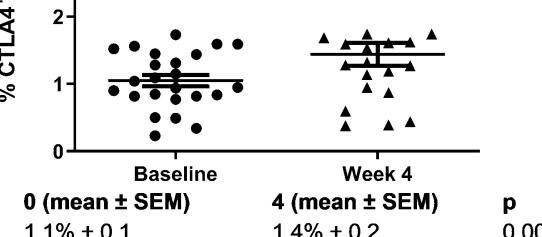

G

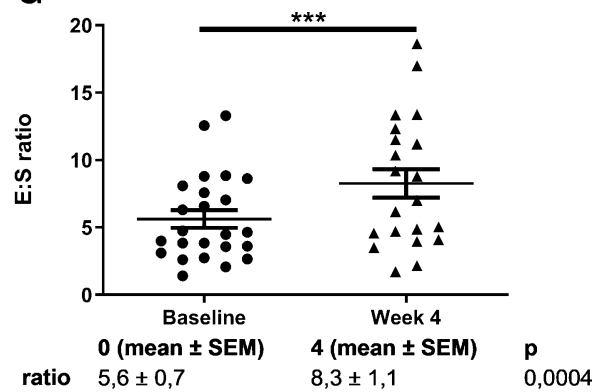

in Tregs and an increase in the E:S ratio, we explored whether changes in these parameters could be related to the outcome. For this purpose, possible correlations between survival (both PFS and OS) and the percentage of Tregs at baseline, the E:S ratio at baseline, the percentage of Tregs at week 4, the E:S ratio at week 4, the percentual change of Tregs from baseline to week 4 and the percentual change in E:S ratio between baseline and week 4 were assessed (Fig. 4a-d, not all correlations shown). Altogether, a correlation between PFS or OS and either the frequency of Tregs, the E:S ratio or changes herein could not be demonstrated. However, it is noteworthy that in the three patients with the longest PFS (i.e., $>1$ year), both a decrease in the percentage of Tregs and 
Fig. 3 Change in NK and DC cell populations between baseline and 4 weeks of treatment. a Percentage of cytotoxic NK cells $\left(\right.$ CD56 ${ }^{\text {dim }}$ CD16 $\left.{ }^{+}\right)$ in PBMC. b Percentage of immunoregulatory NK cells (CD56 ${ }^{\text {bright }} \mathrm{CD} 16^{-}$) in PBMC.

C. Percentage of $\mathrm{cDC} 1$ $\left(\mathrm{BDCA}^{+} \mathrm{CD} 14^{-} \mathrm{CD} 11 \mathrm{c}^{+}\right.$) in PBMC. $\mathbf{d}$ Percentage of cDC2 (BDCA1 ${ }^{+} \mathrm{CD} 19^{-} \mathrm{CD} 14^{-}$ $\mathrm{CD} 11 \mathrm{c}^{+}$) in PBMC.

e Percentage of $\mathrm{pDC}$ $\left(\mathrm{CD} 11 \mathrm{c}^{-} \mathrm{BDCA} 2^{+} \mathrm{CD} 123^{+}\right)$in PBMC. Data were analyzed using paired $t$ tests. ${ }^{*} p \leq 0.05$, $* * p<0.01, * * * p<0.001$
A

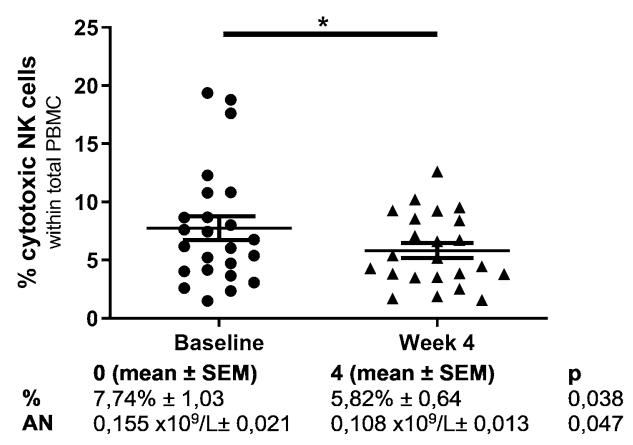

C

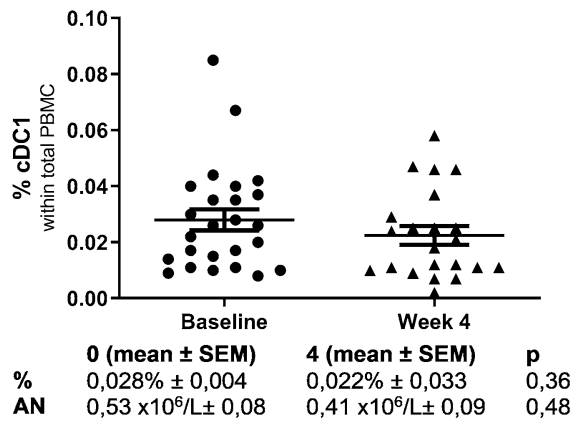

E

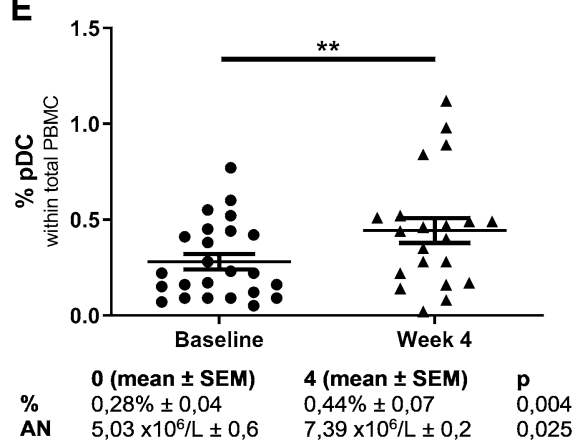

B

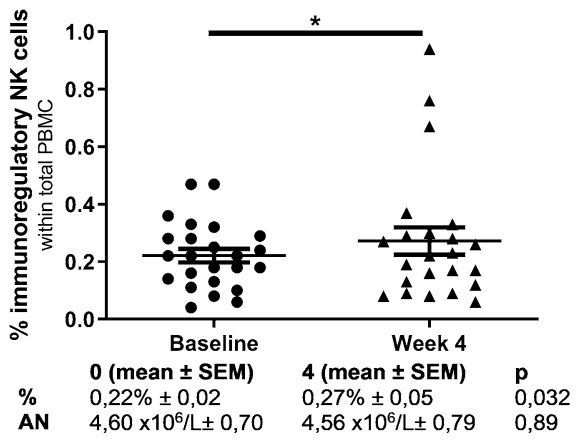

D

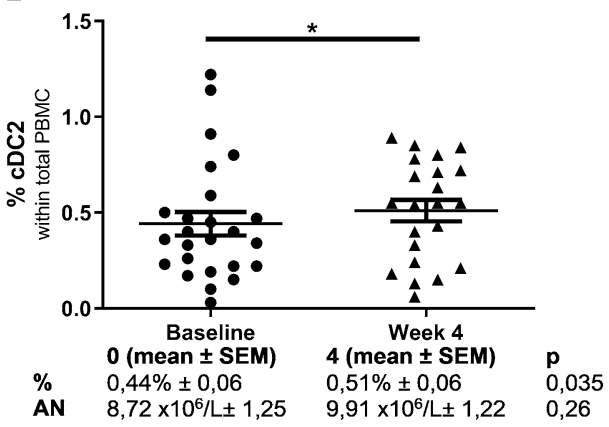

an increase in the E:S ratio between baseline and week 4 was observed.

\section{Discussion}

Overall, the results from the present phase 2 study demonstrate that, while the addition of low-dose oral cyclophosphamide to everolimus treatment in patients with clear cell mRCC effectively prevents the everolimus-induced increase in immunosuppressive Tregs, this does not result in clinical benefit. As the predefined goal of the study of improving the PFS rate at 4 months from 50 to $70 \%$ was not reached, the study was terminated at the preplanned interim analysis.
Several studies have aimed to lower the amount of Tregs in cancer patients by the administration of cyclophosphamide, with varying results $[32,33,41,42]$. As there is controversy on the optimal dose and schedule of cyclophosphamide when aiming for Treg depletion and no such data are available for the combination of cyclophosphamide and everolimus, we first performed a phase 1 study in which we set out to determine the optimal Treg-depleting dose of cyclophosphamide when combined with the standard dose of everolimus [37, 38]. In our phase 1 study, continuous once daily oral dosing of $50 \mathrm{mg}$ of cyclophosphamide proved to be most effective in lowering the percentage of Tregs, and therefore this dose was selected for the present phase 2 study. Of note, while we confirmed that once daily 

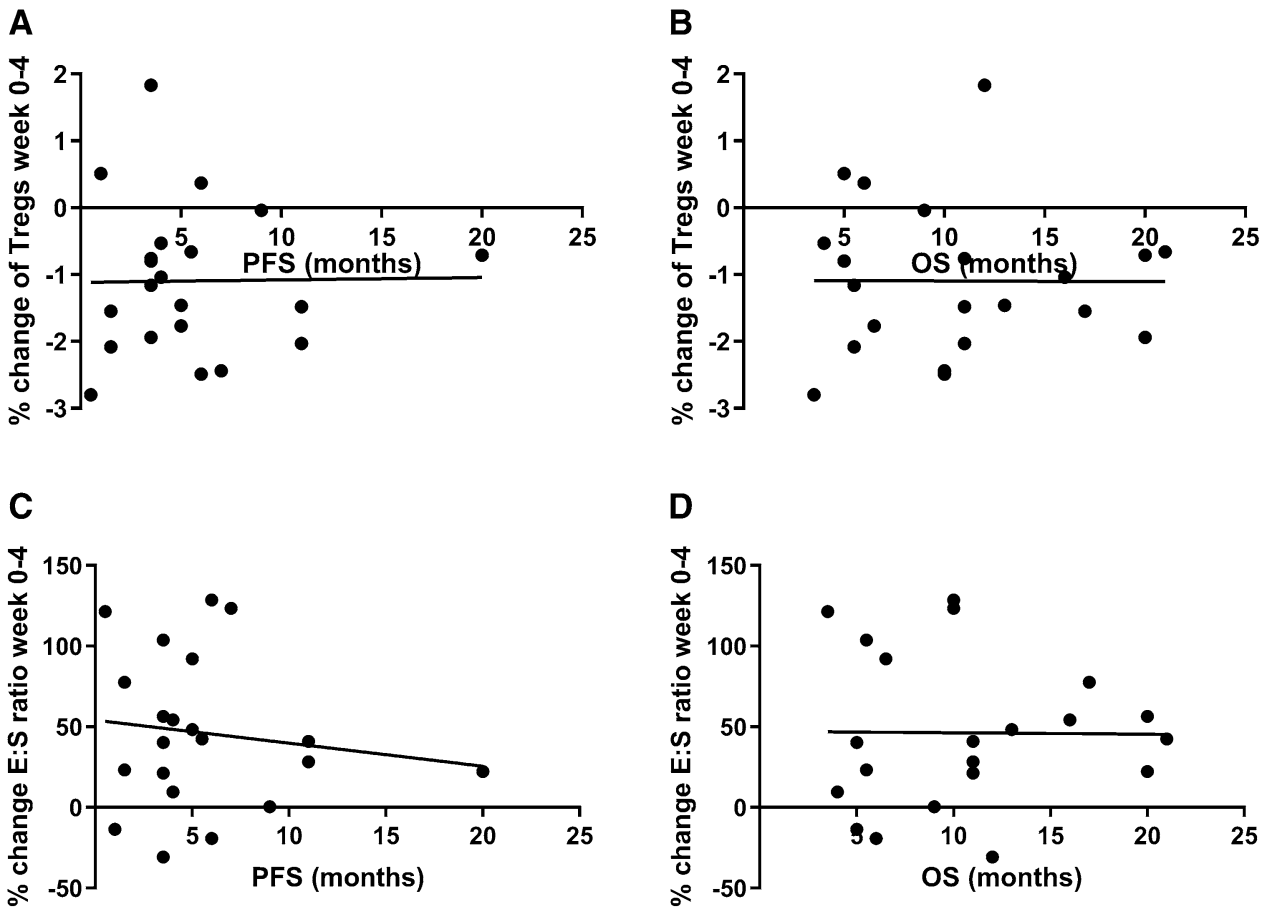

Fig. 4 Correlation between survival and changes in Treg frequency and E:S ratio between baseline and 4 weeks of treatment. a. Correlation between PFS (months) and relative percentual change in the percentage of Tregs between baseline and 4 weeks of treatment, Pearson $r=0.014$ ( $p=0.95)$. b Correlation between OS (months) and relative percentual change in the percentage of Tregs between baseline and 4 weeks of treatment, Pearson $r=-0.004(p=0.99)$. c Correlation between PFS (months) and relative percentual change of E:S

oral administration of $50 \mathrm{mg}$ of cyclophosphamide in this phase 2 trial resulted in a reduction in circulating Treg levels after 4 weeks of treatment, an increase in expression of the proliferation marker Ki-67 was observed in Tregs and this was accompanied by an upregulation of the expression of the inhibitory CTLA- $4^{+}$molecule on Tregs. In accordance with these increased Ki-67 levels, a small rebound in Treg levels was observed after 8 weeks of treatment in the phase 1 part of our study [37, 38]; in the phase 2 part of the study these measurements were not done after 8 weeks. Our observations are in line with results of a study by Ge et al., demonstrating a similar rebound in circulating Treg levels after an initial decrease during the first 14 days of treatment with $50 \mathrm{mg}$ cyclophosphamide once daily in breast cancer patients. This was accompanied by an increase in the proliferative activity of Tregs with a maintained suppressive capacity [33]. Of note, whereas Ge et al. reported a correlation between the temporary reduction in Treg levels and improved clinical outcome, our study showed no relation between a reduction in Tregs and the outcome. Clearly, the clinical impact of cyclophosphamide-induced effects on Tregs may not only differ per selected cyclophosphamide ratio between baseline and 4 weeks of treatment, Pearson $r=-0.133$ $(p=0.564)$. d Correlation between OS (months) and relative percentual change of $\mathrm{E}: \mathrm{S}$ ratio between baseline and 4 weeks of treatment, Pearson $r=-0.011(p=0.963)$. Data were analyzed using Pearson correlation coefficient. Relative percentual change is the percentage of week 4 minus the percentage at baseline, divided by the percentage at baseline

treatment schedule, but also per tumor type as well as any concomitant treatment such as everolimus in our study. Various mechanisms have been implicated as causative factors for the Treg depletion that is observed, such as the mechanisms mentioned earlier, but also low expression of aldehyde dehydrogenase 1 (ALDH1), inhibition of indoleamine 2,3-dioxygenase (IDO), ATP depletion, CCR2 expression and effects on MDSC; however, it is unknown why the effect of cyclophosphamide on Tregs appears to be temporary [43-45].

In our study, the combination of everolimus and cyclophosphamide did not affect the frequency of circulating $\mathrm{CD} 4^{+} \mathrm{T}$ cells and actually resulted in an increased frequency of $\mathrm{CD}^{+} \mathrm{T}$ cells with a concomitant increase in the $\mathrm{E}: \mathrm{S}$ ratio. Though the E:S ratio has previously been reported to be significantly associated with improved survival in cancer patients, we did not find a correlation between E:S ratio and survival [40]. Of note, the association between E:S ratio and survival was mostly reported in studies performing analyses in (peri)tumoral tissues instead of peripheral blood [40, 46, 47]. In our study, no serial tumor biopsies were performed precluding similar analyses. 
Overall, the balance between the monitored immune cell subsets in our study appeared to shift toward a more robust antitumor immune profile, as illustrated by the selective reduction in the percentage of Tregs and increase in effector $\mathrm{CD}^{+}$CTLs as well as blood DC subsets. This did, however, not translate into an enhanced clinical efficacy of combination treatment with everolimus and cyclophosphamide, which may reside in induced changes in the NK cell population, as an increase in the CD56 ${ }^{\text {bright }}$ immunoregulatory NK cell population and a decrease in the CD56 ${ }^{\mathrm{dim}}$ cytotoxic NK cell population were observed. The change in the balance between both NK cell populations can be attributed to cyclophosphamide, as an opposite effect (i.e., a decrease in immunoregulatory NK cells and an increase in cytotoxic NK cells) was observed in the phase 1 patients treated with everolimus monotherapy [31]. A possible explanation might be the preferential apoptosis of CD56 ${ }^{\mathrm{dim}}$ cytotoxic NK cells, as postulated by Bauernhofer et al. [48].

It will be interesting to explore whether therapeutic approaches that can counteract this putative detrimental effect of cyclophosphamide on the NK cell population can improve clinical antitumor activity of the combination of everolimus and cyclophosphamide. For example, the TKI axitinib and the anti-epileptic drug valproic acid have been reported to in vitro increase expression of NKG2D ligands on tumor cells, thereby increasing their susceptibility to NK cell and $\gamma \delta$ T cell recognition $[49,50]$. Alternatively, very low doses of recombinant IL- 2 and IFN- $\alpha$ could be considered, as these were reported to increase NK cell numbers in vivo, albeit that these consisted mainly of the CD56 $6^{\text {bright }}$ cell subset and they will probable increase Treg numbers as well [51]. Potential drawbacks for such triple combination treatment regimens are related to an increased risk of toxicity. For example, studies combining a VEGF TKI with an mTOR inhibitor in $\mathrm{mRCC}$ were mostly terminated prematurely as a result of significant toxicity $[52,53]$.

As stated before, among others, the PD-1 checkpoint inhibitor nivolumab has replaced everolimus as the standard second-line therapy in $\mathrm{mRCC}$ patients. Future studies investigating whether nivolumab can efficiently counteract the immunosuppressive effects observed with everolimus monotherapy may be considered and could potentially result in more potent antitumor activity than either treatment alone.

In conclusion, results from the present phase 2 clinical study demonstrate that addition of low-dose metronomic cyclophosphamide to everolimus can effectively prevent the everolimus-induced increase in Tregs in $\mathrm{mRCC}$ patients and in addition results in an increased frequency of $\mathrm{CD}^{+} \mathrm{CTL}, \mathrm{cDC} 2$ and $\mathrm{pDC}$. The Treg-depleting effect diminished over time (as demonstrated in the phase 1 study $[37,38])$, which may be related to the observed increase in $\mathrm{Ki}-67^{+}$levels in Tregs and was accompanied by a minor increase in Treg CTLA $4^{+}$expression, a decline of cytotoxic NK cells and an increase of immunoregulatory NK cells. Overall, the immunomodulatory effects of the combination of metronomic cyclophosphamide and everolimus did not translate into an altered clinical outcome as measured by the percentage of patients progression free after 4 months of therapy. The comprehensive immunomonitoring analysis performed in this study provides relevant insight for the rational design of future therapeutic approaches in $\mathrm{mRCC}$ and other malignancies such as neuroendocrine tumors, in which mTOR inhibitors are also used as anti-cancer therapeutics.

Acknowledgements This study was part of a clinical study (ClinicalTrials.gov Identifier NCT01462214, Netherlands Trial Register number NTR3085) initiated by the Department Of Medical Oncology of the VU University Medical Center and conducted within the context of the Netherlands Working Group on Immunotherapy of Oncology (WIN-O) with participation of 13 hospitals.

Author contributions IMW, TDG, $\mathrm{CMH}$, and HJV acquired and analyzed the data and drafted and wrote the manuscript. HJV wrote the original protocol for the study. SML, PH, MBP, MT, ML, JBAGH, $\mathrm{HHH}$ and HMV contributed to acquiring the data. All authors read and approved the final manuscript.

Funding The trial was supported by the Dutch Cancer Society (Grant number: VU 2011-5144) and partly funded by a grant from Novartis Oncology Netherlands. Novartis has had no part in study design, data collection, analysis, interpretation, the writing of the manuscript or the decision to submit for publication.

\section{Compliance with ethical standards}

Conflict of interest The authors declare that they have no competing interests.

Ethical approval and standards The study was conducted in accordance with the ethical principles that have their origin in the Declaration of Helsinki and are consistent with International Conference on Harmonization (ICH) Guidelines for Good Clinical Practice. The Medical Ethical Committee of the VU University Medical Center, Amsterdam, the Netherlands (METC, 2011/16) and the Central Committee on Research Involving Human Subjects (CCMO, NL35150.029.11) approved the study protocol.

Informed consent All individual patients gave written informed consent to the use of their blood and data in this study prior to start of treatment.

OpenAccess This article is distributed under the terms of the Creative Commons Attribution 4.0 International License (http://creativeco mmons.org/licenses/by/4.0/), which permits unrestricted use, distribution, and reproduction in any medium, provided you give appropriate credit to the original author(s) and the source, provide a link to the Creative Commons license, and indicate if changes were made. 


\section{References}

1. Ljungberg B, Bensalah K, Canfield S, Dabestani S, Hofmann F, Hora M et al (2015) EAU guidelines on renal cell carcinoma: 2014 update. Eur Urol 67(5):913-924

2. Motzer RJ, Russo P, Nanus DM, Berg W (1997) Renal cell carcinoma. Curr Probl Cancer 21(4):185-232

3. Motzer RJ, Hutson TE, Glen H, Michaelson MD, Molina A, Eisen $\mathrm{T}$ et al (2015) Lenvatinib, everolimus, and the combination in patients with metastatic renal cell carcinoma: a randomised, phase 2, open-label, multicentre trial. Lancet Oncol 16(15):1473-1482

4. Motzer RJ, Escudier B, McDermott DF, George S, Hammers HJ, Srinivas $S$ et al (2015) Nivolumab versus everolimus in advanced renal-cell carcinoma. N Engl J Med 373(19):1803-1813

5. Hsieh JJ, Purdue MP, Signoretti S, Swanton C, Albiges L, Schmidinger $M$ et al (2017) Renal cell carcinoma. Nat Rev Dis Primers 9(3):17009

6. Belldegrun AS, Klatte T, Shuch B, LaRochelle JC, Miller DC, Said JW et al (2008) Cancer-specific survival outcomes among patients treated during the cytokine era of kidney cancer (19892005). Cancer 113(9):2457-2463

7. Giles RH, Choueiri TK, Heng DY, Albiges L, Hsieh JJ, Linehan WM et al (2017) Recommendations for the management of rare kidney cancers. Eur Urol 72(6):974-983

8. Motzer RJ, Hutson TE, Tomczak P, Michaelson MD, Bukowski RM, Oudard $S$ et al., Overall survival and updated results for sunitinib compared with interferon alfa in patients with metastatic renal cell carcinoma. J Clin Oncol 2009 27(22):3584-90

9. Motzer RJ, Hutson TE, Cella D, Reeves J, Hawkins R, Guo J et al (2013) Pazopanib versus sunitinib in metastatic renal-cell carcinoma. N Engl J Med 369(8):722-731

10. Motzer RJ, Rini B, Bukowski RM, Curti BD, George DJ, Hudes GR et al (2006) Sunitinib in patients with metastatic renal cell carcinoma. JAMA 295(21):2516-2524

11. Escudier B, Pluzanska A, Koralewski P, Ravaud A, Bracarda S, Szczylik C et al (2007) Bevacizumab plus interferon alfa-2a for treatment of metastatic renal cell carcinoma: a randomised, double-blind phase III trial. Lancet 370(9605):2103-2111

12. Escudier B, Bellmunt J, Négrier S, Bajetta E, Melichar B, Bracarda $S$ et al (2010) Phase III trial of bevacizumab plus interferon alfa-2a in patients with metastatic renal cell carcinoma (AVOREN): final analysis of overall survival. J Clin Oncol 28(13):2144-2150

13. Rini BI, Halabi S, Rosenberg JE, Rosenberg JE, Stadler WM, Vaena DA et al (2008) Bevacizumab plus interferon alfa compared with interferon alfa monotherapy in patients with metastatic renal cell carcinoma: CALGB 90206. J Clin Oncol 26(33):5422-5428

14. Rini BI, Halabi S, Rosenberg JE, Stadler WM, Vaena DA, Archer L et al (2010) Phase III trial of bevacizumab plus interferon alfa versus interferon alfa monotherapy in patients with metastatic renal cell carcinoma: final results of CALGB 90206. J Clin Oncol 28(13):2137-2143

15. Dabney R, Devine R, Sein N, George B (2014) New agents in renal cell carcinoma. Target Oncol 9(3):183-193

16. Motzer RJ, Escudier B, Oudard S, Hutson TE, Porta C, Bracarda $S$ et al (2008) Efficacy of everolimus in advanced renal cell carcinoma: a double-blind, randomised, placebo-controlled phase III trial. Lancet 372(9637):449-456

17. Agarwala SS, Case S (2010) Everolimus (RAD001) in the treatment of advanced renal cell carcinoma: a review. Oncologist 15(3):236-245

18. Hudes G, Carducci M, Tomczak P, Dutcher J, Figlin R, Kapoor A et al (2007) Temsirolimus, interferon alfa, or both for advanced renal-cell carcinoma. N Engl J Med 356(22):2271-2281
19. Motzer RJ, Escudier B, Oudard S, Hutson TE, Porta C, Bracarda $S$ et al (2010) Phase 3 trial of everolimus for metastatic renal cell carcinoma: final results and analysis of prognostic factors. Cancer 116(18):4256-4265

20. Powles T, Staehler M, Ljungberg B, Bensalah K, Canfield SE, Dabestani $S$ et al (2016) Updated EAU guidelines for clear cell renal cancer patients who fail VEGF targeted therapy. Eur Urol 69(1):4-6

21. Merza H, Bilusic M (2017) Current management strategy for metastatic renal cell carcinoma and future directions. Curr Oncol Rep 19(4):1523-3790

22. Motzer RJ, Tannir NM, McDermott DF, Arén Frontera O, Melichar B, Choueiri TK et al (2018) Nivolumab plus ipilimumab versus sunitinib in advanced renal-cell carcinoma. N Engl J Med 378(14):1277-1290

23. Battaglia M, Stabilini A, Migliavacca B, Horejs-Hoeck J, Kaupper T, Roncarolo M (2006) Rapamycin promotes expansion of functional CD4 + CD25 + FOXP3 + regulatory T cells of both healthy subjects and type 1 diabetic patients. J Immunol 177(12):8338-8347

24. Ruggenenti P, Perico N, Gotti E, Cravedi P, D’Agati V, Gagliardini E et al (2007) Sirolimus versus cyclosporine therapy increases circulating regulatory $\mathrm{T}$ cells, but does not protect renal transplant patients given alemtuzumab induction from chronic allograft injury. Transplantation 84(8):956-964

25. Sugiyama D, Nishikawa H, Maeda Y, Nishioka M, Tanemura A, Katayama I et al (2013) Anti-CCR4 mAb selectively depletes effector-type FoxP3 + CD4 + regulatory T cells, evoking antitumor immune responses in humans. Proc Natl Acad Sci USA 110(44):17945-17950

26. Campbell D (2015) Control of regulatory T cell migration, function, and homeostasis. J Immunol 195(6):2507-2513

27. Griffiths RW, Elkord E, Gilham DE, Ramani V, Clarke N, Stern PL et al (2007) Frequency of regulatory T cells in renal cell carcinoma patients and investigation of correlation with survival. Cancer Immunol Immunother 56(11):1743-1753

28. Shang B, Liu Y, Jiang SJ, Liu Y (2015) Prognostic value of tumorinfiltrating FoxP3 + regulatory T cells in cancers: a systematic review and meta-analysis. Sci Rep 5:2045-2322

29. Li JF, Chu YW, Wang GM, Zhu TY, Rong RM, Hou J et al (2009) The prognostic value of peritumoral regulatory $\mathrm{T}$ cells and its correlation with intratumoral cyclooxygenase- 2 expression in clear cell renal cell carcinoma. BJU Int 103(3):399-405

30. Beziaud L, Mansi L, Ravel P, Lauret Marie-Joseph E, Laheurte C, Rangan L et al (2016) Rapalogs efficacy relies on the modulation of antitumor T cell immunity. Cancer Res 76(14):4100-4112

31. Huijts CM, Santegoets SJ, de Jong TD, Verheul HM, de Gruijl TD, van der Vliet H (2017) Immunological effects of everolimus in patients with metastatic renal cell cancer. Int J Immunopathol Pharmacol 30(4):341-352

32. Ghiringhelli F, Menard C, Puig PE, Ladoire S, Roux S, Martin F et al (2007) Metronomic cyclophosphamide regimen selectively depletes CD4 + CD25 + regulatory T cells and restores T and NK effector functions in end stage cancer patients. Cancer Immunol Immunother 56(5):641-648

33. Ge Y, Domschke C, Stoiber N, Schott S, Heil J, Rom J et al (2012) Metronomic cyclophosphamide treatment in metastasized breast cancer patients: immunological effects and clinical outcome. Cancer Immunol Immunother 61(3):353-362

34. Heylmann D, Bauer M, Becker H, van Gool S, Bacher N, Steinbrink K et al (2013) Human CD4 + CD25 + regulatory T cells are sensitive to low dose cyclophosphamide: implications for the immune response. PLoS One 8(12):e83384

35. Zhao J, Cao Y, Lei Z, Yang Z, Zhang B, Huang B (2010) Selective depletion of CD4 + CD25 + Foxp $3+$ regulatory $\mathrm{T}$ cells by 
low-dose cyclophosphamide is explained by reduced intracellular ATP levels. Cancer Res 70(12):4850-4858

36. Dimeloe S, Frick C, Fischer M, Gubser PM, Razik L, Bantug GR et al (2014) Human regulatory T cells lack the cyclophosphamide-extruding transporter $\mathrm{ABCB} 1$ and are more susceptible to cyclophosphamide-induced apoptosis. Eur J Immunol 44(12):3614-3620

37. Huijts CM, Werter IM, Lougheed SM, Goedegebuure RS, van Herpen CM, Hamberg P et al., Phase 1 study of everolimus and low-dose oral cyclophosphamide in patients with metastatic renal cell carcinoma. Cancer Immunol Immunother, 2018. Epub

38. Huijts CM, Lougheed SM, Bodalal Z, van Herpen CM, Hamberg $\mathrm{P}$, Tascilar $\mathrm{M}$ et al., The effect of everolimus and low-dose cyclophosphamide on immune cell subsets in patients with metastatic renal cell carcinoma: results from a phase I clinical trial. Cancer Immunol Immunother, 2018. In press

39. Huijts CM, Santegoets SJ, van den Eertwegh AJ, Pijpers LS, Haanen JB, de Gruijl TD et al (2011) Phase I-II study of everolimus and low-dose oral cyclophosphamide in patients with metastatic renal cell cancer. BMC Cancer 11:1471-2407

40. Liu F, Lang R, Zhao J, Zhang X, Pringle GA, Fan Y et al (2011) $\mathrm{CD}^{+}$cytotoxic $\mathrm{T}$ cell and $\mathrm{FOXP} 3^{+}$regulatory $\mathrm{T}$ cell infiltration in relation to breast cancer survival and molecular subtypes. Breast Cancer Res Treat 130(2):645-655

41. Ellebaek E, Engell-Noerregaard L, Iversen TZ, Froesig TM, Munir S, Hadrup SR et al (2012) Metastatic melanoma patients treated with dendritic cell vaccination, interleukin-2 and metronomic cyclophosphamide: results from a phase II trial. Cancer Immunol Immunother 61(10):1791-1804

42. Walter S, Weinschenk T, Stenzl A, Zdrojowy R, Pluzanska A, Szczylik C et al (2012) Multipeptide immune response to cancer vaccine IMA901 after single-dose cyclophosphamide associates with longer patient survival. Nat Med 18(8):1254-1261

43. Ahlmann M, Hempel G (2016) The effect of cyclophosphamide on the immune system: implications for clinical cancer therapy. Cancer Chemother Pharmacol 78(4):661-671

44. Loyher PL, Rochefort J, Baudesson de Chanville C, Hamon P, Lescaille G, Bertolus C et al (2016) CCR2 influences T regulatory cell migration to tumors and serves as a biomarker of cyclophosphamide sensitivity. Cancer Res 76(22):6483-6494

45. Kanakry CG, Ganguly S, Luznik L (2015) Situational aldehyde dehydrogenase expression by regulatory $\mathrm{T}$ cells may explain the contextual duality of cyclophosphamide as both a pro-inflammatory and tolerogenic agent. Oncoimmunology 4(3):2162-4011

46. Alvaro T, Lejeune M, Salvadó MT, Bosch R, García JF, Jaén J et al (2005) Outcome in Hodgkin's lymphoma can be predicted from the presence of accompanying cytotoxic and regulatory $\mathrm{T}$ cells. Clin Cancer Res 11(4):1467-1473

47. Sato E, Olson SH, Ahn J, Bundy B, Nishikawa H, Qian F et al (2005) Intraepithelial CD8 + tumor-infiltrating lymphocytes and a high $\mathrm{CD} 8+/$ regulatory $\mathrm{T}$ cell ratio are associated with favorable prognosis in ovarian cancer. Proc Natl Acad Sci USA 102(51):18538-18543

48. Bauernhofer T, Kuss I, Henderson B, Baum AS, Whiteside T (2003) Preferential apoptosis of CD56dim natural killer cell subset in patients with cancer. Eur J Immunol 33(1):119-124

49. Morelli MB, Amantini C, Santoni M, Soriani A, Nabissi M, Cardinali $\mathrm{C}$ et al (2015) Axitinib induces DNA damage response leading to senescence, mitotic catastrophe, and increased NK cell recognition in human renal carcinoma cells. Oncotarget 6(34):36245-36259

50. Yang F, Shao Y, Yang F, Liu M, Huang J, Zhu K et al (2013) Valproic acid upregulates NKG2D ligand expression and enhances susceptibility of human renal carcinoma cells to NK cell-mediated cytotoxicity. Arch Med Sci 9(2):323-331

51. Pavone L, Fanti G, Bongiovanni C, Goldoni M, Alberici F, Bonomini S et al (2009) Natural killer cell cytotoxicity is enhanced by very low doses of rIL-2 and rIFN-alpha in patients with renal cell carcinoma. Med Oncol 26(1):38-44

52. Molina AM, Feldman DR, Voss MH, Ginsberg MS, Baum MS, Brocks DR et al (2012) Phase 1 trial of everolimus plus sunitinib in patients with metastatic renal cell carcinoma. Cancer 118(7):1868-1876

53. Kanesvaran R, Watt K, Turnbull JD, Armstrong AJ, Wolkowiez MC, George D (2015) A single-arm phase 1b study of everolimus and sunitinib in patients with advanced renal cell carcinoma. Clin Genitourin Cancer 13(4):319-327

Publisher's Note Springer Nature remains neutral with regard to jurisdictional claims in published maps and institutional affiliations. 